\title{
Medyanın Kadın Cinayetlerine Bakışı: 2009-2013 Dönemi Ayşe Paşalı ve Münevver Karabulut Cinayet Haberleri Örneği
}

\author{
DOI: 10.26466/opus.976225
}

\author{
$\underline{\text { Safure Cantürk* }}$ \\ ${ }^{*}$ Dr., T. C. Cumhurbaşkanlığı, Ankara/Türkiye \\ E-Posta: safurecanturk@gmail.com \\ ORCID: $\underline{0000-0002-5419-3325}$
}

\begin{abstract}
Öz
Kitle iletişim araçlarının milyonlarca insanı söylem üzerinden etkisi altına almasıyla birlikte şiddet olayları ile medyanın şiddet haberlerini ele alış biçimi arasında doğrudan ilişki bulunmaktadır. Bu bağlamda son yıllarda kadına şiddet haberleriyle birlikte Aile İçi Şiddetin Önlenmesini içeren İstanbul Sözleşmesi medyada tartışma konusu olmuştur. Türkiye'nin 2011 yılında imzaladığ̊ İstanbul Sözleşmesinden 10 yıl sonra neden çıktı̆̆ı, sözleşme ile şiddet arasındaki ilişkinin nasıl olduğunu doğru anlayabilmek için Türkiye'nin sözleşmeyi imzaladığ̆ döneme ve medyanın o dönemdeki diline ışık tutmak gerekmektedir. Bu çalışma, Türkiye'nin 2011 yılında İstanbul sözleşmesine imzalama sürecini kapsayan 2009-2013 döneminde medyanı kadın cinayetlerine bakışın ve bu haberlerdeki söylemini sorgulamaktadır. Medyanın kadın cinayetlerine bakış açısını sorgulayan bu araştırma, kamuoyunda bilinen sembol davalardan Ayşe Paşalı ve Münevver Karabulut cinayetlerini konu olan Hürriyet, Sabah, Haber Türk, Milliyet, Cumhuriyet, Radikal, Vatan gazetelerinde ilgili 41 haberi sorgulamıştır. Araştırmada ilgili haberler kadın cinayetleri, başlıklar, haber yapma biçimi, metin içeriği ve imaların kapsayacak şekilde söylem analizi yöntemi ile ele alınmıştır. Sonuç olarak medyada kadın cinayetlerinin incelendiği dönemde öldürülen kadınları 'namuslu/namussuz', 'hak eden/hak etmeyen' ve 'zengin/fakir' gibi ataerkil cinsiyetçi ve sinıfsal ayrımlarla kadın cinayetlerinin haberleştirildiği görülmüştür. Medyanın haberdeki söylemi şiddetin yeniden üretimine zemin hazırlarken aynı zamanda yargı sürecindeki kararlarda ve politika yapıcılar üzerinde kamuoyu baskısı oluşturabilmektedir.
\end{abstract}

Anahtar Kelimeler: Medya, Kadına Yönelik Şiddet, Toplumsal Cinsiyet, Söylem Analizi, Ayşe Paşall, Münevver Karabulut. 


\title{
The Media Perspective towards Femicides: 2009-2013 Period Case of Ayşe Paşalı and Münevver Karabulut Murder News
}

\begin{abstract}
As the media discourse influences millions, violence and media perspectives towards violence news are directly related. The Council of Europe Convention on Preventing and Combatting Violence Against Women and Domestic Violence, Istanbul Convention, has been a topic of discussion in the media. The relationship between the Convention and violence has revived with Turkey's withdrawal. To comprehend Turkey's withdrawal reason after signing it in 2011 and the Convention and violence relationship, the period and media language of that time should be enlightened. This study analyses media perspectives towards femicides and news discourse between 2009-2013, including Turkey's process of signing the Istanbul Convention. The research examines 41 news from Hürriyet, Sabah, Haber Turk, Milliyet, Cumhuriyet, Radikal, Vatan, newspapers writing about Ayşe Paşalı and Münevver Karabulut murders, exemplar cases known by public. In this research, news is approached through discourse analysis involving the headlines, reporting, content, and implications. Consequently, it is revealed that the femicides during this period were reported with a patriarchal, sexist and class division such as 'honourable/dishonourable', 'deserving/undeserving', 'rich/poor'. This discriminatory language leads reproduction of violence. The media discourse could create public pressure on judicial decisions and policymakers.
\end{abstract}

Keywords: $\quad$ Media, Violence Against Women, Gender Mainstreaming, Discourse Analyses, Ayşe Paşall, Münevver Karabulut. 


\section{Giriş}

Ataerkil ideolojinin kökenleri avcılık toplumlarına kadar dayanmasına rağmen, batıda gelişen sömürgeci anlayışla birlikte kurduğu 'ben ve öteki' arasındaki ilişki toplumsal hayatta 'norm' haline gelmiştir. Ataerkil ideolojinin hüküm sürdügü toplumlarda 'beyaz, batıll, erkek' en üstte güçlü ve 'norm' olarak kabul edilirken, kadın yaratılış itibariyle güçsüz ve zayıf olarak sınıflandırılmıştır. Erkek öznedir (ben), mutlak olandır, kadın ise öteki cinstir. Ataerkil toplumlarda kadın erge göre, yani norm kabul edilen geçerli sayılan cinse göre, eksik, edilgen, güçsüz, duygusal ve yeteneksiz diye tanımlanır (Beauvoir, 1993, s.17). Gerek bireyler arasındaki ilişkiler gerekse toplumların çeşitli kurumlarındaki iş ve özel ilişkiler kadınlarla ilgili gelenekselleşmiş bu önyargılarca düzenlendiğinden en bağımsız kadın bile bu çarpık görüşlerin etkisinde kalır. Bilincinde olarak ya da olmayarak kendini korkunç bir kısır döngünün içinde bulur. İkinci Seks'de 'İnsan kadın doğmaz, kadın olur' denirken, cinsiyet kavramının aslında biyolojik değil, toplumsal olduğu ilk kez vurgulanmış olur (Doltaş, 1995, s.51).

Hemen hemen tüm toplumlarda kadın cinselliğinin ve doğurganlığının denetimi konusunda birleşen ataerkil yapılar, denetimi aynı zamanda toplumda kurucu bir işlev olarak da görmektedir. Ataerkil ideolojinin yapısı, cinsiyet ve iktidar arasındaki ilişkiyle doğrudan ilişkilidir. Ataerkillik cinsiyetler arası hiyerarşiye dayanan bir toplumsal yapı olarak da tanımlamaktadırlar (Millet, 1987, s.26). Kadın ve erkek arasındaki hiyerarşi, cinsiyetten kaynaklanmakta, ezen (erkekler) ve ezilen (kadınlar) iki sınıf yaratan bir politika olarak ortaya çıkmaktadır. Cinsiyet ve toplumsal cinsiyet eşitsizliklerinin cinsellikle ilişkisini tartışan akademisyenler, hegemonik cinsiyet ve cinsellik söyleminin, cinsiyet eşitsizlerinin altında yatan dinamiklerden biri olduğun öne sürmekte ve toplumsal bir adalet sorunu olarak tanımlamaktadır (Milet, 1987, s.6-45). Akdeniz ve Ortadoğu toplumlarında ise kadın erkek arasındaki bu hiyerarşik ilişki toplumsal değerlere göre şekillenmektedir. Örneğin namus, kadının cinsel ahlakının göstergesi, erkeğin ise sahip olduğu kadının koruyucusu, 'onur/şerefi olarak tanımlamaktadır. Böylelikle kadın/erkek bedenleri düzenlenmekte, dolayısıyla cinsiyet eşitsizliği üzerinden yükselen geleneksel ataerkil yapı biçimlendirilmektedir (Lughod, 2004, s.97.140). 
Eril şiddet olarak tanımlanan kadına yönelik şiddet ise her ne kadar ataerkil toplumlarda gözüktügü belirtilmiş olsa bile tüm toplumlarında kendini farklı türlerle göstermektedir. Kadına yönelik şiddet, kimi toplumlarda kültürel nedenler, kimi toplumlarda ekonomik olarak kendini gösterse de fiziken olduğu kadar ekonomik ve toplumsal olarak da güçlü olan erkeğin zayıf olan kadın üzerinde uyguladığı baskı olarak da tanımlanabilir. Kadına yönelik şiddetin yayılmasında cinsiyetler arasında eşitsiz güç ilişkilerinin yanı sıra medya kuruluşlarının bu eşitsizliği söylemi ile yaygınlaştırması da etkilidir. Medyanın haber söyleminde güçlüden yana tavır alınması ve güçlü dayanışması üzerine kurulması ikincil durum olan kadınlara yönelik şiddetin devamını sağlamaktadır (Dursun, 2010, s.21). Liberal ekonomide dördüncü kuvvet olarak tanımlanan medya toplumsal algı değişiminde doğrudan rol almaktadır. Medyanın siyasi ve ekonomik bağlantıları ile birlikte reklama dayalı sansasyonel habercilik anlayışı kadına ilişkin haberlerin en önemli konusu haline getirmektedir. Medya haberlerinde kullandığı söylem ile toplumdaki ataerkil bakış açısını aynen topluma tekrar yansıtmakta ve bu bakış açısı yeni nesiller üzerinde pekişerek toplumsal cinsiyet rollerini olduğu gibi kabullendirmektedir (Şener vd., 2016 s.166). Kadına yönelik şiddet haberleri medyada, magazinleştirilerek ya da cinayetlerin sebeplerine yönelik mesajlarla kadına yönelik şiddet meşrulaştırılmaktadır (Yaktıl, 2010 s.446; Yegen, 2014, s.19-20).

Türkiye'de uzun yıllar medyada kadın cinayetlerine ilişkin haberler genel itibariyle iki egemen söylem üzerine kurulmuştur. Türk Ceza Kanunu'nun (TCK) 'kadın cinayetlerinde namus ve töre ayrımının' etkisinde kalan bu söylemlerde, kadın cinayetlerinin namus ve töre cinayeti olarak ele alınır (Hamzaoğlu, Konuralp, 2018, 67-83). TCK'da, etnik bir grubun aile meclisi kararıyla gerçekleştirdiği cinayetleri 'töre cinayeti' olarak görüp ceza artımı gösterilirken, 'Haksız Tahrik İndirimi', (TCK, madde 81) 'namus' cinayetlerinde erkeğin lehine uygulanması medyaya da kadın cinayetleri 'namus' ve 'töre' cinayeti olarak yansır (Doğan, 2016, s.126-160).

Ancak son yıllarda medyada töre dışındaki kadın cinayetlerinin de kendi içinde ikiye ayrıldığı gözlenmektedir. Mahkemelerinin kadın cinayetlerinde 'haksız tahrik' indirimi uygulaması, haberlerde hak eden/ hak etmeyen ya da namuslu/namussuz kadın vurgusuyla işleyerek, ataerkil 
ideoloji ve toplumsal cinsiyet ayrımcllı̆̆ının medya aracılığılyla normalleştirilmesinin göstergesi olarak medya, bu durum toplumsal cinsiyet ayrımcılığının medya aracılığıyla normalleştirilmesini sağlamaktadır. Bu gösterge, aldattığ 1 için kocası tarafından öldürülen kadın cinayeti haberlerine üçüncü sayfada yer verilirken, kocasını aldatmamış iyi eş/anne modelindeki kadın cinayetlerinin ise birinci sayfadan medyatikleştirilmesi ya da sembolleştirilmesi bu göstergeye örnektir. Şüphesiz medyada metinsel ve söylemsel özelliklerine göre kadıların temsil biçimleri de farklılaşmaktadır (Tanrı̈̈ver, 2007, s.156). Bu çerçevede ideolojilerin büyük oranda söylem yoluyla edinildiği akılda tutulduğunda yaygın medyanın cinsiyetçiliğin yeniden üretiminde üslendiği işlevler daha anlaşılmaktadır. Zira ideoloji söylemde ifade edilir ve yeniden üretilir (Dijk, 2003, s.47).

Türkiye medyasının gündemine son yıllarda kadına yönelik şiddet ya da namus cinayetleri içeriği ile çok sayıda haber taşınmaktadır. Türkiye'de de kadına yönelik şiddet vakaları dünya ortalamasının üzerinde seyretmektedir. TBMM Kadına Yönelik Şiddetin Sebeplerinin Araştırılması Komisyonu'na sunulan rapora göre 2021 yılında Türkiye'de 15 yaşından büyük yaklaşık her 3 kadından 1'i yaşamının herhangi bir döneminde fiziksel ve cinsel şiddetin birine ya da her ikisine maruz kalmıştır. Türkiye'de kadın cinayetleri de her yıl resmi artmaktadır. 2009'da öldürülen kadın sayısı 172 iken, 2010'da 165, 2011'de 155, 2020 yılında 267 olarak kayıtlara geçmiştir (Ocak, 2021).

Ülkedeki tüm haber medyası bu cinayetleri açık bir dille eleştirmekte ancak diğer taraftan adı geçen cinayetlerin beslendiği ataerkil cinsiyet ve cinsellik söylemini her gün yeniden üretmektedir. Dahası cinayeti işleyenin namusa ilişkin mazereti bu öldürme eyleminin meşru görülmesinde ya da eleştirilmesine önemli bir veri olarak ele alınmaktadır. Sözü edilen konuya ilişkin basın tarafından geliştirilen dilin kadına yönelik şiddet haberleri özelinde analiz edildiği bu çalışma, Türkiye'deki kadına yönelik şiddeti konu alan diğer tartışmalarla birlikte düşünüldüğünde anlam kazanacaktır.

Türkiye'de kadına yönelik şiddet, kadın, erkek, tek tek bireyler, sağ, sol, merkez tüm ideolojiler, medya ve devlet tarafından "Hiçbir şekilde" kabul edilemez görünmesine rağmen şiddetin nedeni "namus" ise şiddeti yok saymak hatta bireyin yaşam hakkını elinden alınmasını haklı 
görmeye neden olmaktadır. Bunun yanı sıra medyanın şiddet haberlerinde, duruma göre reklam veren, güçlü, sermaye sahiplerinin lehine, sınıfsal duruma göre tavır takındığını da sergilenmektedir.

Bu çalışmada kadına karşı şiddet konulu haberlerde kullanılan söylemin ataerkil cinsiyet/cinsellik söylemine eklemlendiği ve sözü edilen haberlerin kadına karşı şiddeti normalleştirdiği savunulmaktadır. Söz konusu varsayımlar, kadın cinselliğini ve namusu konu alan feminist literatürdeki tartışmalardan beslenmekte ve kadına şiddet haberlerinde söylem analizi yöntemiyle incelenmesine dayanmaktadır.

Haberlerin analizinde, kadına yönelik şiddetin, ataerkil cinsiyet ve cinsellik ve burjuvazi/sınıf söylemlerine eklemlenme noktalarının neler olduğu sorusuna yanıt aramaktadır. Bu sorunun yanıtı, kadına şiddeti konu edinen bu haberleri biçimlendiren cinsiyetçi ataerkil yaklaşımlara görünürlük kazandırması, farkındalık oluşturulması, yargı kararları ve politika yapıcılar üzerinde etkili olmaktadır.

Kadına şiddetin, ataerkil ideolojide medya temsiliyle normalleştirilmesi ile ilgili olarak çalışmada Ayşe Paşalı ve Münevver Karabulut Cinayetlerine ilişkin yazılı medyada yer alan seçilmiş haberlerin söylem analizleri yapılmıştır. Türkiye medyasında kadına şiddet haberlerinin üçüncü sayfadaki diğer şiddet haberlerinden ayrışarak birinci sayfada yer almasıyla medyanın bu cinayetlere bakış açısında da değişiklik olmuştur. Medyanın bakış açısındaki değişim, kamuoyunun kadın cinayetlerine yönelik tepkisini çekerken, yargı ve politika yapıcıların da konuya bakış açısını değiştirmiştir. Çalışmanın 2009-2013 yılları arasında Ayşe Paşalı ve Münevver Karabulut cinayet haberlerini seçmesinin iki önemli sebebi bulunmaktadır. Birincisi, kamuoyunda'sembol dava' olarak bilinen Ayşe Paşalı'nın 2009 yılında kocası tarafından öldürülmesinin ardından Avrupa İnsan Hakları Mahkemesi devletin vatandaşını koruyamadığı için Türkiye Cumhuriyetini tazminata mahkûm etmiştir. Bunun üzerine Türkiye, medya üzerinde oluşan kamuoyu baskısı ve içinde bulunan siyasi konjoktürün etkisiyle 2011 yılında İstanbul Sözleşmesini (Kadına Yönelik Şiddetin Önlenmesi ve Aile İçi Şiddetin Önlenmesi ve Bunlarla Mücadele Hakkında Avrupa Konseyi Sözleşmesini) dünyada ilk taraf ülke oldu. Sözleşme, 2012 yılında TBMM tarafından onaylandı ve 2014 yılında yürürlüğe girmiştir. Aynı süreçte Münevver Karabulut cinayeti ise kamuoyunda hem işleniş biçimi hem de 
zanlının sınıfsal farklılığı nedeniyle ülke gündeminde yer almış ve kadın cinayetlerinde sembol dava olarak kabul edilmiştir.

İşte bu araştırma İstanbul Sözleşmesinin imzalanma sürecinde doğrudan etkili olan sembol davalara konu olan haberlere odaklanarak, 20092013 yılları arasındaki Ayşe Paşalı ve Münevver Karabulut cinayetleri özelinde ele almaktadır. Araştırma, medyada kadına yönelik şiddet haberlerinin ataerkil cinsiyet/cinsellik ve burjuvazi/sınıf söylemlerine eklemlenme noktalarının neler olduğu sorusuna yanıt aranmaktadır? Bu cinayet vakalarının seçiminde ise medyanın bu cinayet vakalarını ele alış biçimleri ve kategorik olarak ayrıştırması nedeniyle seçilmiştir. Bu nedenle çalışmada söylem analizi yöntemi kullanılmaktadır. Haberlerin incelendiği bulgular bölümüne geçmeden yöntem bölümünde araştırmasın soruları, örneklem seçimi, söylem analizine ilişkin olarak geliştirilen akademik tartışmalar kısaca özetlenmiş ve son olarak sonuç ve tartışma bölümü ele alınmıştır.

\section{Yöntem}

Araştırma 2009-2013 yılları arasında Türkiye'nin İstanbul Sözleşmesini imzalama sürecinde Türk basının kadın cinayetlerine bakışına odaklanmıştır. Ayşe Paşalı ve Münevver Karabulut cinayet haberleri, kadın cinayetlerinde sembol dava olmaları, bu açıdan Türkiye'nin İstanbul sözleşmesini Sözleşmenin imzalanmasında etkili olmaları, kamuoyunda ve basında geniş yer tutmaları sebebiyle örneklem olaraksöz konusu cinayet haberleri seçilmiştir. Türkiye'nin yazılı medyasında Hürriyet, Sabah, Habertürk, Milliyet, Cumhuriyet, Radikal, Vatan gazeteleri olmak üzere (toplam 7 gazetede) Ayşe Paşalı ile ilgili 12, Münevver Karabulut ile 29 olmak üzere toplam 41 haber seçilmiştir. Söylem analizi için birinci sayfada yer alma, cinayetin ilk işlendiği dönemdeki ilk haber, davanın seyrini belirleyen önemli süreçleri, söz konusu cinayet ve davalara ilişkin önemli röportajlar, kamuoyunda tartışmaya yol açacak önemli başlık ve içerikler, ile mükerrek olmayacak şekilde ön öncelemede tasniflenmiş ve 17 haberin söylem analizi gerçekleşmiştir. Gazete seçiminde ise her olayın özelinde konuyu daha yaygın olarak ele alış biçimi, gazetenin tirajı ve hedef kitlesine göre muhafazakâr/seküler/milliyetçi ve 
merkez medya diye kendi içinde ideolojik olarak ayrışan gazeteleri kapsaması dikkate alınmıştır.

Seçilen haber metinleri Teun Van Dijk'ın Eleştirel Söylem Analizi yöntemi ile ele alınacaktır. Çalışmada kullanılan gazetelere internet arşivlerinden online olarak ulaşılmıştır. Farklı ideolojilere sahip gazetelerin Ayşe Paşalı ve Münevver Karabulut cinayet haberlerinde söylem benzerlikleri ve farklılıkları tespit edilmeye çalışılmıştır.

Örneklem alınan haberlerin analizinde, kadına yönelik şiddetin, ataerkil cinsiyet ve cinsellik ve burjuvazi/sınıf söylemlerine eklemlenme noktalarının neler olduğu sorusuna yanıt aramaktadır. Araştırmada, farklı ideolojiye sahip gazetelerin kadına yönelik şiddet ve kadın cinayeti haberlerini oluştururken kullandığ cinsiyetçi dil söylem analizi yöntemiyle tespit edilmiştir. Örneklem sayısal olarak temsil niteliği taşımamakla birlikte nitel araştırma tekniklerinin kullanıldığ haberlerin söz konusu medyanın kadına şiddet ve namus özelinde takip ettiği ataerkil cinsiyetçi, sınıfsal ve milliyetçi söylemi örneklemek açısından yeterli olduğu düşünülmektedir.

Her metnin içinde farklı fikirler, ideolojiler ve gizli anlamlar vardır. Van Dijk medya metinlerindeki örtük anlamların ortaya çıarılması, verilmek istenilen mesajların anlaşılması, haberlerin yarattı̆̆ incelenmesi için söylem çözümlemesi kullanmıştır. Eleştirel söylem çözümlemesi alanında yapılan çalışmalardan en önemlisi haber metinlerinin üzerinde olduğunu belirten Dijk (1988)'de özellikle haber metinleri ve bağlam arasındaki ilişkiyi ele almıştır. Dijk' e göre medya söylemi her kesimden insanlar için çok önemlidir. Aynı zamanda bilgi, tutum ve ideolojilerin esas kaynağıdır. Milyonlarca insan, dünyada yaşanan birçok önemli olayı (örneğin savaşlar, anlaşmalar) medya aracılı̆̆ıyla öğrenir. Bu insanların her biri basında ve televizyonda çıkan haber metinlerini farklı şekilde paylaşır, yorumlar. Haber söyleminin ne kadar güçlü bir etkisinin olduğu bu yüzden çok önemlidir. Toplumsal, siyasi, kültürel ve ekonomik iktidarın uygulama biçimini ve ideolojileri anlamak için haberin başlıkları, üslubu ve şemaları iyi şekilde incelenmelidir (Dijk, 1999).

Bağlamsal boyutlar, bilişsel süreçler, sunumlar ve sosyo-kültürel faktörler gibi bağlamın çeşitli özellikleri söylem analizinde son derece önemlidir. Bir haberin bağlamı, onun hangi ideolojilerce biçimlendirildiğini gösteren en önemli kısmıdır. Diğer bir deyişle etkileşim, yalnızca metnin 
bize ne söylediği ile ilgili değil, aynı zamanda bağlamın ne anlattığı ile yakından ilgilidir. Söylemi kontrol etmek, aynı zamanda bağlamı da kontrol etmeyi gerektir (Dijk, 2010, s.9-14). Medyaya erişen ve yönlendirme erkini elinde bulunduran kişiler, bağlam üzerinde egemenlik kurma yanında söylemin temel noktaların belirlemektedirler (Dijk, 2010, s.17). Bu temel noktaların ve başlıkların belirlenmesi ve manipüle edilmesi aslında bir yeni zihinsel alt yapı-model oluşturmasını sağlamaktadır. Söylemin en önemli bilgisini temsil eden, söylemin ne ile ilgili olduğunu anlatan bu boyut, hangi iktidar ilişkilerinin dolayımından geçerek oluşturulduğunu kavramak için önemlidir (Dijk, 2003, s.67).

Ayrıca medyanın siyasi kişilerle kurduğu yakın ilişkiler haberin söylemine yansımaktadır. Medya iktidarın ya da siyasilerin yaptığ çalışmaları ve uygulamaları kamuoyu ile pozitif bir şekilde paylaştığında, toplumun büyük bir kısmının düşüncelerini olumlu yönde etkileyebilme gücüne sahiptir. Ya da tam tersi negatif içeriklerle de toplumun siyasilere bakışını olumsuz etkileyebilmektedir. Bu ilişkiler sonucunda medya ekonomik fayda sağlarken, iktidar ise yerini sağlamlaştırmaktadır (Bulunmaz, 2009 s. 339-341). Burada iktidar tanımlaması, tek başına siyasi hükümeti ifade etmemekte, toplumdaki sosyo-ekonomik sermaye sahiplerini, medya üzerinde etkili olabilecek farklı güç odaklarını ifade etmektedir. Toplumda farklı siyasi ve ekonomik güç ve sermaye sahiplerinin olması, farklı ideolojideki gazetelere ve bu gazetelerde aynı haberlerin farklı şekillenmesine yol açmaktadır. Bu sebeple haber metinlerinde verilmek istenilen ideolojik fikir ve egemen söylemi açı̆̆a çıkarmak için söylem analizi yöntemine başvurulmuştur. Buna rağmen kadına yönelik şiddet haberlerinde benzer söylemlerin ortaya çıkması siyasi ideolojilerin üstünde birleştikleri toplumsal söylemi de işaret etmektedir (Kabadayı, 2006, s.113). Bu çalışmalara kadına karşı şiddet ve namus cinayetlerine ilişkin söylemin hangi iktidar ilişkilerinin içinden geçerek oluşturulduğuna ve hangi ideoloji tarafından nasıl şekillendiğine görünürlük kazandırılacaktır. Zira söylem zaman, yer, sosyal, kültürel ve ideolojik bağlam içinde anlam kazanır. 


\section{Bulgular}

Ayşe Paşalı: Bu başlık altında 9'i Hürriyet, 3'ü Haber Türk, 2'si Cumhuriyet, 1' Vatan gazetelerinde olmak üzere toplam 12 haber incelenmiştir. Ayşe Paşalı, 27 Mart 2009 tarihinde eşinden öldüresiye dayak yemesine rağmen, eşi mahkemede 'pişmanım' diyerek serbest bırakılmıştır. Boşanma davası açan Ayşe Paşalı eşinin ölüm tehditleri nedeniyle mahkemeye başvurmuş, ancak evlilik birliği kalmadığı için talebi reddedilmiş. Daha sonra ise 2010 yılında boşandığ 1 eşi tarafından sokak ortasında bıçaklanarak öldürülmüştür (Haber Türk Gazetesi 2010, 27 Mart, s. 5). Bunun üzerine Ayşe Paşalı ismi ve davası, kadın sivil toplum kuruluşları ve medya tarafından 'Sembol Dava' olarak yakından takip edildi. Ölümünden sonra davayı sürdüren Ayşe Paşalı'nın yakınları, Avrupa İnsan Hakları Mahkemesine başvurmuştur. Mahkeme, 'Devletin (kanunların), kadını koruyamadığı' kararını vermiş Türkiye'yi tazminata mahkûm etmiştir. Bu dava, Türkiye Avrupa Parlamentosu'nda kadına yönelik şiddetin önlenmesine ilişkin hukuki düzenlemeleri koruma altına alan İstanbul Sözleşmesi'nin hazırlanmasında öncü olmasına ve ilk imzacı olmasında etkili olmuştur.

İncelediğimiz tüm haberlerde öteki/suçlu "koca” ve koruma kararı vermeyen "mahkeme/savcı" suçlu/öteki ilan edilmiştir. Konu olay özelinde ele alınmıştır ancak gazetelerin tamamında olay sadece aktör üzerinden değil aynı zamanda sistem üzerinden, geçmiş kararlara da vurgu yapılarak eleştirilmiştir. Bu önemli çünkü haberin kaynağı olarak sadece mahkeme kararı değil aynı zamanda sivil toplum örgütleri, muhalif örgütlere de yer verilmiştir. Devletin ihmalinin can aldığı haber metinlerinde sıklıkla vurgulanmış, hâkim cinsiyet ve cinsellik söylemi tartışmaya açılmakta ve devletin bu sistemin bir parçası olduğuna vurgu yapılmaktadır. Böylelikle incelenen haberlerin kamuoyunda oluşturduğu sonuçları itibariyle, medyanın gücünü hem pozitif olarak hem de negative kullanabildiği görülmektedir. Kadına şiddet konusu, ücüncü sayfa haberlerindeki adli vaka olan şiddet haberlerinden çıkarılarak, birinci sayfadaa konu yapılarak kamuoyunun dikkatini çekmiş, siyasi karar alıcılardan sorunun çözümüne yönelik taleplere sebep olmuştur. Ancak bunu yaparkenki biçimi ataerkil söylemin dolaylı yoldan işlenmesiyle şiddetin kendini yenileyerek artmasına da zemin hazırlamıştır. 
İncelenen haberlerde özellikle merkez medyanın öncüsü Hürriyet gazetesi bir taraftan sistemi eleştirirken diğer taraftan sistemin savunuculuğunu yapmış, mahkemelerin tahrik indiriminde 'namuslu/namussuz durumuna göre tahrik indirimini uyguladığ ${ }_{1}$ belirterek, sistem üzerinden öldürülmeyi hak eden kadınlar hak etmeyen kadınlar vurgusunu yapmaktadir.

Hürriyet Gazetesi'ndeki ilgili haberlerde sürekli cinayetin sebebine vurgu yapılmış, sanığın ifadeleri ‘başlık ve manşet' gibi görünür şekilde yer vermektedir. "Bir akrabasının dügününde dayısının oğluyla dans etmiş...", "Herkes birbiriyle dans edebilir ama benim karım edemez..." ifadeleri (Hürriyet 8.2.11) hem toplumsal ataerkil zihniyeti gösterirken aynı zamanda merkez medya bu sebepleri "Kocasını aldatan" kadın olarak görmeyip, olayı "Namuslu/iyi anne/eş" olarak yer veriyor. Bu şekilde, mahkemenin tahrik indirimi vermemesiyle de "Ayşe Paşalı namusluydu ve öldürülmeyi hak etmedi" mesajı verilmiştir.

Olayla ilgili olarak dönemin Kadın ve Aileden Sorumlu Devlet Bakanı Selma Aliye Kavaf'ın röportajlarında; "Hâkimin kararı sorunlu", "Yasalarımızda eksik yok", "Münferit" ifadelerinin başlığa çıkarılması devletin sistemi savunmaya devam ettiğini göstermektedir (Hürriyet 30.12.10; Vatan 26.12.10). Özellikle, siyasilerin kadına yönelik şiddet haberlerinde medyanın kamuoyunda eleştiri gelecek ifadeleri başlığa çekerek kamuoyunun siyasilere yönelik tepkisini de çekmiştir.

Haberlerde, Ayşe Paşalı sınıfsal konumu itibariyle töre cinayetlerine kurban gitmeyecek kadar eğitimli, batıll, kentli ve Türk'tür. Diğer taraftan namus cinayetlerine kurban gitmeyecek kadar da namuslu/iyi bir annedir. Özetle medya için var olan toplumsal kalıp-yargılar Paşalı cinayetinin tanımlanması açısından yetersizdir. Bu durumda yine hegemonik cinsiyet ve cinsellik söyleminin önemli bir öğesi olan namuslu-namussuz kadın ayrımı çağrılmakta ve haber dili bu ayrım aracılığıyla inşa edilmektedir. Haberin eklemlendiği söylemlerin başında Paşalı cinayetinin "haksız" bir cinayet olduğu gelmektedir. Haksızdır çünkü Paşalı, namuslu, iyi bir annedir, ölümü hak etmemiştir. Bu ayrım öteki kadınların, yani namus ve töre cinayetlerine kurban giden kadınların ölümünü meşrulaştırmaktadır. Bu haberlerin tümünde imalar, üstü kapalı anlatımlar vardır. Özellikle Paşalı'nın ölüm sebebinin sadece dayısının oğluyla yaptığı bir dans 
olduğunun sıkça hatırlatılması, söylenmek istenip de açıç̧a söylenemeyene işaret eder: Kuzenle dans namussuzluğun göstergesi değildir. Bu durumda Paşalı ölümü hak etmemiştir. Bu çerçeve erkeğin haklı nedenleri varsa kadına şiddet uygulayabilir düşüncesinin onayıdır. Boşanan her kadının eski eşinin şiddetine açık hale gelebileceği mesajları ile yüklü bu haberlerde orta sinif/kentli okuyucuya seslenilmektedir: Sen de şiddetin nesnesi olabilirsin. Kendini her türlü aksaklıktan ari sanan orta sınıf/eğitimli/kentli, namusuyla yaşayan kadınların bile namus cinayetlerine kurban gidebileceğini gösteren bu haberler çift anlamlılığıyla ataerkil ideolojiyi iki yönlü beslemektedir. Birincisi boşanan her kadının namus cinayetine kurban gitme potansiyelinin olduğudur. İkincisi ise adına kadın cinayeti dedikleri namus cinayetlerinin bir sistem sorunu olmadığ 1 aksine "münferit bir vaka" olduğudur. İki yönlü işleyen bu söylemle bir taraftan kadın cinayetlerinin, esas dinamiği olan namusla ilişkisi kesilir diğer taraftan ise erkek şiddetinin yanlış adım atan her kadının başında Demokles'in kılıcı gibi sallandığı hatırlatılır. Bu iki söylem tam da egemen cinsiyet ve cinsellik söyleminin bir uzantısıdır. Bunların yanı sıra medya, Paşalı cinayeti haberlerinde kanun ve mevzuattaki eksiklikler, polis ve hakim gibi süreçlerin adli yönden yürütücülerinin çelişkili aldığ uygulamalar, STK'ların cinayetlere ilişkin bu tür uygulamalara yönelik eleştirilerine kapsamlı olarak, geniş yer vermesi kamuoyu farkındalı oluşturmuş ve toplumsal talepler siyasilerin ilgili konuya ilişkin harekete geçirmiştir. Paşalı davası'nın AİHM sürecini yakından izleyen medya aynı zamanda siyasi karar alıcıların kadına yönelik şiddetin önlenmesine ilişkin İstanbul Sözleşmesini imzalamasında, konuyu sorunsallaştırarak etkili olduğu görülmüştür.

Münevver Karabulut: Bu başlık altında Milliyet, Radikal, Sabah, HaberTürk gazetelerinde Cinayetinin işlendiği Mart 2009 ile mahkeme kararının açıklandığ 1 Kasım 2011 tarihlerini kapsayan zaman diliminde 29 haber, eleştirel söylem çözümlemesi yöntemiyle incelenmiştir. 3 Mart 2009 tarihinde İstanbul Etilerde bir çöp konteynerinde Münevver Karabulut'un cesedi, başı gövdesinden ayrı olarak bir gitar kutusunda bulunmuştur. Münevver Karabulut'un erkek arkadaşı olan iş adamı Hayyam Garipoğlu'nun yeğeni Cem Garipoğlu, cinayetin zanlısı olarak aranmaya başlamıştır. Cem Garipoğlu'nun aynı gece evini apar topar terk ettiği be- 
lirlenmiş, asayiş şubesinde sorgulanan Cem' in babası Nida Garipoğlu, annesi Makbule Tülay Garipoğlu ile cesedi korsan taksiyle taşıyan taksici gözaltına alınmış, çıkarıldıkları mahkemece tutuksuz yargılanmak üzere serbest kalmışlardır. Cinayetin 56. gününde baba Nida Garipoğlu cinayete iştirak ve oğluna yardım etmekten tutuklanmıştır. Cinayetten yaklaşık 90 gün sonra ise 186 ülkede interpol tarafından kırmızı bülten ile aranan katil zanlısı Cem Garipoğlu cinayetin 197. gününde avukatı tarafından Bahçelievler' de avukatları tarafından polise teslim edilmiştir.

Sabah Gazetesinde 30 Mayıs 2009 tarihinde yer alan haberde Münevver Karabulut ve Cem Garipoğlu'nun tanışma öykülerini anlatılmakta, hem mağdurun hem de zanlının öyküleri yansız bir ifadeyle sunulmaktadır. Haber, Cem Garipoğlu'nun aslında, ailenin daha çok babanın kişisel hırslarının yarattı̆̆ 1 bir "kişilik" olduğuna, dünyada yaygın konuşulan tüm dilleri öğrenmesi uğruna anne ve baba sevgisinden ve tabi ki özdeşim sürecinden yoksun kalarak, göçebe, küçük yaştan itibaren aileden uzak bir yaşam sürdüğüne vurgu yapılmaktadır. Bu haberde yer alan Cem'in bir arkadaşının Garipoğlu'na ait bir ek kartı çalarak harcama yapmasıyla ilgili anne Garipoğlu'nun polise suç duyurusunda bulunması bilgisi, bu cinayetin bütününe bakıldığına çok önemli bir çelişkiyi göz önüne sermektedir. Arkadaşının ailesinin şikâyetçi olmayın lütfen önerisini, "Herkes suçunun bedelini ödemeli" açılamasıyla ret eden anne Garipoğlu'nun oğlunun cinayet gibi büyük bir suçun delillerini karartma ve kaçısına yardım çabası bu çelişkiyi ifade etmektedir.

Sabah Gazetesi 6 Kasım 2011 tarihli Münevver Karabulut'un annesi Nagehan Karabulut ile yapılan röportaj, incelenen tüm haberler içerisinde en nesnel, öyküyü katışıksız biçimde veren, uygun sorularla olayın ve annenin düşüncelerini anlaşılır kılan, bu cinayetin nedenleri, süreci ve yaratacağı sonuçlarıyla uygun açıklamalar içeren bir haber olarak değerlendirilebilir. Röportajda, mahkemelerin "adil yargılama yapması", "hafifletici sebepleri kolaylıkla değerlendirmeye almaması", "sorumluların hak ettiği cezayı alması", "Bakanın konuya gereken ilgiyi göstermesi" yönünde beklentiler yer almaktadır. Ayrıca anne Karabulut, medyanın "fakir kız-zengin genç" kurgusunun doğru olmadığını ifade etmekte, sınıfsal olarak alt değil orta sınıfa ait olduklarını özellikle hatırlatmaktadır. Röportajda dikkat çeken en önemli bulgulardan birinin de çocuk istismarı ve çocuğa yönelik şiddeti önlemek üzere çalışan 
avukatların (İstanbul Barosunun Gelincik Projesi), Cem Garipoğlu'nun avukatlığını üstlenmelerinin yarattığı paradoks durumdur. Bu durumun anne Karabulut'un zihninde "Adil Dünya" alg1sını sarsan bir nitelik taşıyacağını söyleyebiliriz. Anne Karabulut'un bu sarsıntısı "Kuzu postuna bürünmüş kurt" ifadesiyle kimlik bulmaktadır. Bu röportaj haberin önemli diğer bir vurgusu ise, bu olayın bu tip cinayetlerin işlenme sıklığının artışına özendirici oluşudur. Bunu önlemenin yolunun adaletin doğru karar vermesiyle olabileceğine dikkat çekmektedir. Röportajın sözü edilen olumlu yanlarına rağmen Sabah gazetesinin Münevver Karabulut cinayet haberlerinin sunumunda "Cinayetten şok görüntüler" başlığı ile kanlı giysiler, testere gibi görselleri sunarak sansasyonel habercilik yapmiştır.

Milliyet Gazetesi 4 Mart 2009 tarihli “Etiler'de Vahşet” başlıklı ilk haberde, cinayetin işleniş şekliyle ilgili tüm ayrıntılar, başlık, spot, giriş olmak üzere haberin her cümlesinde vurgulandığ1 görülmektedir. Bunun yanında, babanın ünlü bir şef olduğu ve mağdur Karabulut'un başarılı bir öğrenci olduğu ABD ve Kanada'da dil eğitimi gördüğü bilgileri de verilmektedir. İlk haberde Münevver Karabulut'un ünlü bir şefin kızı olduğu, iyi bir eğitim aldığı, yurtdışında dil eğitimi gördüğ ü detaylarının yer almasına rağmen daha sonraki haberlerde zanlının daha üst sınıftan ünlü ve zengin bir aile olduğunun ortaya çıkmasıyla birlikte "fakir kızzengin oğlan" senaryosunun kurgulanmıştır. Bu durum medyanın haberlerde sınıfsal ayrıma göre gerçeği manipüle ettiğinin göstermektedir.

Milliyet Gazetesinin 30 Haziran 2009 tarihli “Çapkın'dan ilk değerlendirme" başlıklı haberi, devleti temsil eden güvenlik güçlerinin en üst düzeydeki yöneticilerinin, basına yaptığı açılamalarla cinayeti aydınlatmada Garipoğlu ailesi ile işbirliği yapıldığı izlenimi edinilmektedir. İstanbul Valisi Muammer Güler'in açıklamasında, gazetecilerin, "Aile ile işbirliği yapıyor musunuz?" sorusuna karşılık, "İşin adli boyutu olduğu ve bu kapsamda polisin her türlü çalışmayı yaptığı, ailesiyle değişik şekilde kurulan bağlar olduğu" ifadesiyle bu iddiayı desteklemektedir.

Milliyet Gazetesinde 8 Temmuz 2009 tarihli “Adli Tıp skandalında flaş gelişme" başlıklı haberde, Karabulut'a otopsi yapan adli tıp uzmanlarının ve diğer teknik elemanların eldiveninde bir başka kişinin sperminin bulaşmasıyla ilgili skandal konu edilmektedir. Bu durum, hem mağdurun 
ailesinin hem de kamu oyununun bilimsel nitelik taşıyan referans kurumlara karşı güvensizlik duymalarına yol açtığı söylenebilir. Ayrıca bu durum Karabulut ailesinin yaşadığı travmanın boyutlarını daha da artırmaktadır. İkincil travma-yeniden travma olarak adlandırılan bu süreç Karabulut ailesinin travmalarının kronikleşmesine ve onarımın daha da güçleşmesine yol açacak bir durumdur.

Milliyet Gazetesinin 17 Eylül 2009 tarihli, “Garipoğlu sonunda teslim oldu" başlıklı haberinde, cinayeti anlaşılır kılmaya değil Cem Garipoğlu'nun duygusal ve psikolojik durumu öne çıkarmaya yönelik bir çaba dikkat çekmektedir.

19 Kasım 2009 tarihli, "Baba oğul cinayeti birlikte işledi” başlıklı haberde ise, daha çok cinayetin nasıl gerçekleştiği, savcıların cinayetin niteliğini tanımlayarak ağırlaştırılmış müebbet cezası isteği ve olayın planlı bir cinayet olduğuna ilişkin vurgu yer almaktadır. Bu haber cinayetin ayrıntılarını, nedenlerini, sürecini, mahkeme seyrini anlaşılır biçimde özetlemekle birlikte son bölümde yer alan, "Teğmen: Aramızda hiçbir şey geçmedi" ara başlığı ile daha önce medyada "kıskanç" iddialarını geçersiz olduğunu kanitlayan ifadeler yer almaktadır. Her ne kadar bu haberde cinayete ilişkin nesnel bilgiler, uygun bir dille aktarılmış olsa da medyanın olayın genelinde cinayete "kıskançlık" vurgusuyla Garipoğlu ailesini olumlu, cinayeti "namus kavraminda kabul edilebilir", Karabulut'u ise "öldürülmeyi hak etti" algısını kamuoyunun zihninde değiştirmeye yetmediği görülmektedir.

Radikal Gazetesi, cinayet ve sonrasındaki süreçle ilgili haberlerini çeşitli düzeylerde ele aldığı görülmektedir. Karabulut ve Garipoğlu'nun geçmişi, cinayetin oluş şekline ilişkin haberlerde teknik bir dil kullanarak ayrıntılı bir söylem kurarken, adli tıp ve polisle ilgili gelişmelerde daha eleştirel bir yaklaşım sergilemiştir. 4 Nisan 2009 tarihli, "Münevver'in katilini bulun mitingi" başlıklı haberinde cinayete ilişkin toplumsal kitle tepkilerine yer verilmiştir. 13 Haziran 2009 tarihli, "Linç girimine destek verdi, mağdurları bol miktarda gaz tüketip cop eskitti" başlıklı haberde, dönemin İstanbul Emniyet Genel Müdürü Celalettin Cerrah'ın ataerkil ideolojinin çok tipik bir örneği olan "Kızlarına sahip çıksalardı" açıklaması konu edilmiştir. Genel olarak haber bütününde Cerrah'ın, daha önceki uygulama ve söylemlerinde şiddeti öven, zanlı Cem Garipoğlu'nu 
haklı k1lan, Karabulut'un ailesini suçlayan ifadeleri devletin söyleminin de ataerkil ideoloji ile eklemlendiğini göstermektedir.

Radikal Gazetesi 9 Eylül 2009 tarihli, "Münevvere Sperm Eldivenden Bulaşmış" başlıklı haberde ise olayın ne kadar ciddiyetsiz şeklide araştırıldığına vurgu yapmaktadır. Bu durum dava sürecinin her aşamasının medya tarafından takip edilmesi, davanın ilerleme aşamasında kamuoyunun takibini sağlamakta ve güvenlik, yargı ve ilgili diğer kamu kurumlarının üzerinde de baskı oluşturmaktadır.

Radikal Gazetesinde yar alan 13 Eylül 2009 tarihli, “Cem'i basın yakaladı!" başlıklı haberde, Garipoğlu'nun yakalanması sürecinde, medyada bilgi kirliliğinin de yaşandığı ve zaman zaman gerçek dışı haber ürettiğine dikkat çekilmektedir. İlginç olan noktalardan biri ise medyanın kendi ürettiği yalan haberi yeniden haberleştirmesidir. 19 Eylül 2009 tarihli, "Teslime kim karar verdi?" başlıklı haberde ise, medyanın polis teşkilatı ile Garipoğlu ailesi arasındaki ilişkinin çarpıklığına dikkat çekilmekte, polisin beklenen görevlerini yapmadığını ve Garipoğlu'nun Savcı yerine polise gittiğine işaret edilmektedir. Ayrıca, haberde Garipoğlu'nun saklanması sürecinden kendisine yardım edenleri polisin koruduğu, Garipoğlu'nun ise saklanmasında polisin bilgisinin olduğu izlenimine yer verilmiştir.

Haber Türk Gazetesi 18 Kasım 2011 tarihli, “Cem Garipoğlu'nun cezası belli oldu" başlıklı yazıda cinayetin ağır tahrik altında işlendiği ve Münevver'le fırtınalı aşk yaşarken başka erkeklerle mesajlaşmasını kaldıramadığına vurgu yapılmaktadır. Haberde kullanılan söylem, şiddeti göstereni "tahrik altında kalmış masum"', şiddet mağduruna namusa ilişkin gönderme yaparak, "ölümü hak etti” izlenimini vermektedir.

Çalışmaya konu olan Münevver Karabulut cinayeti haberlerinde cinsiyetçi, elitist ve ataerkil/devletçi ideolojiyi örnekleyen söylemler tespit edilmiştir. Bu söylemlerin devletin orta sınıf-erkek doğasını açığa çıkarttığ 1 düşünülmektedir. Bunlardan ilki cinsiyetçi ideolojiye örnek oluşturan söylemlerde Karabulut ailesinin ve Münevver Karabulut'un ahlaki yapısının sorgulanmasıdır. Söz konusu haberlerde yer alan namus vurgusu ile cinsiyetçi ideolojiyle eklemlenen bu haberler ataerkil yapının yaygınlaştırılması ile normalleştirilmesine hizmet etmektedir.

Hemen tüm gazetelerin iç sayfalarda ilgili haber metni fotoğrafla ile yer almaktadır. Bu fotoğrafların dehşet içerikli olmaları yanında cinselliğe 
ve güzelliğe ağırlık veren fotoğraflar olması cinayet haberleri yanında Münevver Karabulut'un "seksi" kıyafetleriyle yer alması haberde kadının cinsel obje olarak kullanıldığı izlenimini de vermektedir. Ayrıca, Karabulut'un söz konusu fotoğraflarıyla birlikte haber başlıklarında "Kıskançlık cinayeti", "Başka bir erkekle mesajlaştı", "Aldattı" vurgularıyla da namussuz ve öldürülmeyi hak eden söylemi ile cinayet normalleştirildiği görülmektedir.

Tüm haberlerin spotlarında Karabulut'un başının testere ile kesilerek öldürüldüğü vurgusunun yapılması erkek ideolojinin yansıması olarak değerlendirilmedir. Haberin en etkili yerinde cinayetin nasıl işlendiğine ilişkin ayrıntıların verilmesi okuyucuda örseleyici etkiyi artırmaktadır. Haberi okuyan ve saldırganla özdeşim ve saldırganlık potansiyeli taşıyanlarda şiddetin olabilirliği/normalliği pekiştiriliyor ve saldırgan rol modele dönüşmektedir. Diğer taraftan mağdur olma potansiyeli taşıyanlarda söz konusu söylem bireyin korkusunu, şiddete karşı sinmesini ve boyun eğmesini pekiştiriyor. Bu durum, eril şiddetin medya aracılı̆̆ıyla yeniden üretiminin tipik örneği olarak değerlendirilmektedir.

İlgili haber metinlerinin söylemlerinde özellikle bağlamı elitist ideoloji oluşturmaktadır. Ayrımcı bir dile sahip olan elitist ideolojinin haberlere eklemlenme biçimi ise öldürülen Münevver Karabulut'un babanın mesleği, Garipoğlu ailesinden talep ettiği tazminat gibi veriler ekseninde görünür hale gelmektedir. Mesela tazminat davasının geleneksel toplumlardaki kan-namus parası gibi iki bedel ile benzeştirildiği söylenebilir. Zira kan ve namus parası mağdur edilen güçsüz ailenin fail güçlü aileden talep ettiği bir maddi bedeldir. Haberlerin veriliş biçimi olayın konusu olan tarafların sınıfsal yapısından doğrudan etkilenmektedir. Suçu işleyen bireyin, burjuvazinin üst düzey ailelerinden biri olması ve bu ailenin sermayenin önemli bir temsilcisi olarak ekonomik/siyasi gücü haberin verilişini doğrudan biçimlemiştir. Medya haber içeriklerinde suçu işleyen kişiyi ve ailesini "hoş görebileceği zihinsel bir söylem" oluşturarak toplumsal algıyı maniple etmeye çalışmıştır. Medyanın haberi sunarken, her ne kadar mağdurun yanında gözükse de haberlerin satır aralarında ve sistemi temsil edenlerin ifadelerinde üst sınıfı koruyan bir dil geliştirdiği dikkat çekmektedir. Haberlerde Garipoğlu ailesinin sunuluş biçimi sınıfsal konumlarını koruyan ve kayıran bir işlev gördügü izlenimi vermiştir. Mağdurun tüm yaşam öyküsü kişilik özellikleri ve ailesel yapısının 
ayrıntılı bir şekilde verilmesine karşın olayın ilk günlerinde Garipoğlu ve ailesinin ismi ve görüntüsü haberlerde yer almamıştır. Daha sonraki haberlerde ise Garipoğlu'nun yedi dil bilmesi, yurtdışında eğitim görmesi gibi olumlu özelliklerinin sunulması, sınıfsal yapı bağlamında zanlının ve ailesinin korunduğunu ve zanlıya karşı toplumda bir sempati yaratıldığını düşündürmektedir. Cem Garipoğlu'nu 50 avukatın savunacağına vurgu yapılması cinayetin işlenmesi ve zanlının kaçırılmasında şüpheli olan baba Garipoğlu'nun oğluna nasihatlerine yer verilmesi, yine cinayetin gizlenmesinde suç ortağı olan şüpheli olan anne Garipoğlu'nun, oğluna yönelik açıklamalarının "duygusal" bir dille verilmesi, ailenin sınıfsal yapısından kaynaklanan güç asimetrisinin göstergesi olarak değerlendirilebilir.

Son olarak Karabulut cinayet haberlerinde, devletin, özellikle de güvenlik güçlerinin olaydaki sorumluluğu bağlamında devlet ideolojisinin de güçlüden yana söylem geliştirdiğini göstermektedir. Dönemin Emniyet Genel Müdürü Celalettin Cerrah'ın "Kızlarına sahip çıksalardı" biçimindeki erkek egemen söylemin kendini net olarak gösterdiği ve mağdur ailenin gerçek suçlu olduğunu düşündüren açıklamasının medyada yer alış biçimi ataerkil ideolojinin devletin dilinde de meşrulaştırılarak yeniden üretildiğinin göstergesidir

\section{Tartışma ve Sonuç}

$\mathrm{Bu}$ çalışma kapsamında incelenen haberlerde, medyanın haberlerde kullandığı söylem ile toplumsal alg1 oluşturma, yargı kararlarını etkileme ve politika yapıcıların tutumlarını değiştirme yönünde iki yönlü gücü olduğu görülmektedir. Medya bu gücünü kullanırken geçmişten bu yana toplumun var olan ataerkil ideolojinin söylemlerini kullanmaya devam ederek, kısır döngü içinde bu ideolojinin yayılmasını sağlamaktadır.

Medya, sağ-sol, muhafazakâr, ulusalcı, liberal yayın politikası fark etmeksizin kadın cinayetlerinde aynı 'karşı duruş' bakış açısıyla haberlere yer vermektedir. Ancak medya kadına şiddetin sorumlusunu yine kadının 'ahlaksız/uygunsuz/namussuz' davranışları olarak değerlendirmektedir. Namuslu, namussuz kadın ayrımları ile öldürülmeyi hak eden ve hak etmeyen kadın söylemiyle toplumda kadına şiddeti dolaylı yoldan meşrulaştırmaktadır. 
Haberlerde kadına yönelik belli kalıplar ile önyargılar öne çıartılarak kadınların evinde oturması gereken pasif bireyler değerlendirmesi, medyanın kadın temsilinde öncelikli sorunu olarak görülmektedir.

Türk Ceza Kanunu'nda cinayet suçlarında uygulanan 'Tahrik İndirimi', kadın cinayetlerinde erkekten, yani erkeğin namusunu kurtarmasından yana kullanılması da ataerkil ideolojinin sadece medyada değil, hegomonik ideolojinin unsurları olan hukuk sisteminde de kendini göstermektedir. Ayrıca, adaletin uygulayıcı polis, savcı, hâkim gibi devleti temsil edenlerin de yine kadına karşı, ataerkil söylemin ifadelerini eklemlendikleri görülmektedir. Bu şekilde medya, kalıp önyargılarla kadına şiddetin hatta öldürülmesini hangi durumlarda kabul edilebileceğini, hak eden/hak etmeyen şeklinde söylem geliştirerek, kadına karşı şiddeti toplum tarafından normalleştirmesine neden olmaktadır. Böylelikle kadına karşı şiddet, 'gelenek've 'kültür' adı altında toplum tarafından ve yeni nesil tarafından da içselleştirilmektedir

Haberlerde kadın ve erkek gücünün eşitsizliği, erkeklerin fiziksel olduğu kadar sosyal ve ekonomik gücünün kadın üzerindeki etkisi ataerkil söylemler kullanılarak yeniden üretilmektedir. Kadın cinayetleri öfke, aşk, kıskanma, aldatılma gibi kavramlarla meşrulaştırılmaktadır. Kadın cinayetlerinin nasıl işlendiğine ilişkin ayrıntılar sık sık tekrarlanarak kadınlara yönelik bir korku politikası oluşturulurken, potansiyel şiddet gösterebilecek kişilere karşı da şiddeti normalleştirmekte hatta rol model olabilmektedir.

Medya, haberlerde objektifliğini her zaman güçlüden yana bozarken, kadına karşı erkeği, fakire karşı da zengin yanında yer almaktadır. Bu ayrımı medya, yer verdiği kadın cinayetleri haberlerinde de yapmaktadır. Kadın cinayetinin haber olabilmesi için ünlü, zengin, yabancı ya da hunharca öldürülmesi gibi özellikler ile reyting getirici özellikleriyle sayfalarına taşımaktadır. Ancak medya sınıfsal ayrımını her zaman zengin ve güçlüden yana kullanmakta, üst sınıftan olanların yapmış oldukları kabul edilemez suçlar bile sempatik bir söylem ile haberlerde yer almaktadır. Bu durumda, işlevi, sistemi sorgulamak, yanlış giden işleri ve yapılmayanları ortaya çıkarmak olan medyanın aslında 'Kimsesizlerin' medyası olmadığını göstermektedir. 
İncelenen haberlerde medya, kadın cinayetlerini benzer ifadeler, benzer başlıkları ile adeta aynı elden yazılmış gibi sunması medyanın toplumsal ataerkil söylemi içselleştirdiği ve buna uygun bir dili inşa ederek reyting için vazgeçilmez bir unsur olarak kullandığının izdüşümüdür.

Bununla birlikte, şiddet haberlerinin, kadına şiddet haberleri başlığ altında medyada geniş yer bulması, sorunsallaştırılması, kamuoyunun tartışmaya açılması, ilgili STK'ların igili mevzuat ve hukuki eksikliklerine ilişkin görüşleri, siyasi gündemi de etkilemiştir. Bu dönemde söz konusu cinayetlerin sembol dava haline gelmesi, AİHM sürecinin kamuoyunda yer bulması, kamuoyu beklentileriyle siyasi karar alıcılar İstanbul Sözleşmesi'ni kabul ederek imzalamışlar ve seçim süreçlerinde olumlu icraatler kapsamında yer vermişlerdir. Bu durum, 10 yıl sonra İstanbul Sözleşmesi'Nin iptal edilmesinde medyanın sözleşme ve kadın cinayetlerine ilişkin söylemlerinin etkilerini tekrar incelemeye ihtiyaç olduğunu göstermektedir.

Çalışma kapsamında incelenen her iki kadın cinayetinde de görülüyor ki medya haberlerinde toplumsal cinsiyet eşitliğinden hareket etmiyor. Haber dilinde, erkeksi/ataerkil bakış açısı belirleyici olmaktadır Medya ile toplum arasında toplumsal cinsiyet eşitsizliğini sürekli karşılıklı besleyen kısır döngünün kadına şiddetin normalleştirilmesinde en etkili araç olduğu görülmektedir. Diğer taraftan, şiddet sorunun içinden kadına şiddeti ayrı bir sorun olarak birinci sayfadan daha geniş yer vermesi ve tartışmaya açması, ilgili alandaki mevzuat ve hukuki eksikliklerin çıkmasına sebep olarak siyasi karar alıcıları da harekete geçirmiştir. Toplumsal algı gücü yüksek olan medyanın, toplumu ve karar alıcı mekanizmaları doğrudan etkileyen en etkili araç olduğu görülmektedir. Bu nedenle haber için olay yerine ilk giden, kaynakları ilk ağızdan dinleyen, kurgulayıp yazan muhabirler, muhabirin haberini editöryal süzgeçten geçirip sunuş biçimini belirleyen editor ve yazişleri sorumlularına toplumsal cinsiyet eşitliğine ilişikn mutlaka farkındalık eğitimleri verilmesi gerekmektedir. Toplumun medyayı değil, medyanın toplumu yönlendirdiği göz önüne alındığında medyadaki haberleri sunuş biçimde gerçekleşecek değişikliğin toplumun algısında da pozitif değişikliğe yol açacaktır.

Sonuç olarak, medya kadına şiddet haberlerinde kullandığı ataerkil söylem ile şiddetin toplumda haklı sebeplerle devam etmesine dolaylı 
olarak sebep olurken, kadına şiddet konusunu sorunsallaştırarak, kamuoyunun gündemine getirmesine ve siyaset yapıcıların çözüm noktalarında harekete geçmesini sağlayabilmektedir. Kadına şiddet sorununu kaynağından çözebimek için medya mensuplarının cinsiyet eşitliğine ilişkin söylem farkındalığı eğitimi almaları, bu yönde ilgili STK'ların obdusmanlığı ile söylemlerini değiştirmeleri sağlanabilir. Bunun yanı sıra, yazılı ve görsel haberler başta olmak üzere medyada cinsiyet ayrımcılığ 1 ve şiddetin her türlüsünün, özellikle kadına yönelik şiddetinin özendirilmesine karşı durulmalı, şiddetin olağan bir insanlık hali olarak sunulmasını engellemek için bilinçlendirme çalışmaları yapılmalıdır. Yazılı, görsel basın ve film gibi kültür sanat ürünlerinin kadını aşağılayıcı ifadelere yönelik toplumsal tepkiler ve yaptırımlar uygulanmaladır. 


\section{EXTENDED ABSTRACT The Media Perspective towards Femicides: 2009- 2013 Period Case of Ayşe Paşalı and Münevver Karabulut Murder News

\author{
* \\ Safure Cantürk \\ Presidency of the Republic of Turkey
}

Due to the media's feature to cover large masses, it could directly impact the behaviors of individuals and societies. Social violence cases and the way media addresses the violence cases are directly related to each other. In Turkey, there is a direct relationship between cases of violence against women and the discourse used while media addresses cases of violence against women. In order to understand correctly why Turkey withdrew from the İstanbul Convention 10 years after signing it in 2011 under fighting against domestic violence and the relationship between the Convention and violence, it is necessary to shed light on the period when Turkey signed the Convention and the media language of that time.

This study analyses the media perspective towards femicides and the discourse of news during the 2009-2013 period, including Turkey's process of signing the İstanbul Convention in 2011. In this study, 41 relevant news from Hürriyet, Sabah, Haber Türk, Milliyet, Cumhuriyet, Radikal, Vatan newspapers writing about Ayşe Paşalı and Münevver Karabulut murders, which are symbol cases known by the public are examined in a way to involve the femicides, headlines, reporting, text content and implications.

In this study, it is defended that the discourse used in news about violence against women is articulated to patriarchal sex/sexuality discourse and mentioned news normalize violence against women. The aforementioned assumptions are supported by discussions in feminist literature dealing with women's sexuality and honor and are based on the analysis of the violence against women through the discourse analysis method. In the news analysis, it is searched for an answer to the question of what the points of articulation of violence against women to patriarchal sex and sexuality and bourgeoisie/class discourses are. The answer to this question 
is influential on making the sexist patriarchal approaches forming the news about violence against women apparent, creating awareness and judicial decisions and policy makers.

Regarding normalizing violence against women in patriarchal ideology through media representation, in the study, discourse analysis of selected news from the written press about Ayşe Paşalı and Münevver Karabulut Murders is performed. The media perspective towards these murders has changed since the news about violence against women was separated from other violence cases on the third page and placed on the first page. While attracting reactions from the public on women against women, the change in media perspective has changed the perspectives of jurisdiction and policy makers on this matter. There are two significant reasons why the news on Ayşe Palalı and Münevver Karabulut murders is selected between 2009 and 2013 in this study. The first reason is that after Ayşe Palali, whose case is known as a 'symbol case' by the public was killed by her husband in 2009, the European Court of Human Rights convicted the Republic of Turkey to indemnity on the ground that it could not protect its citizen. Hereupon, Turkey became the first party to the İstanbul Convention (the Council of Europe Convention on Preventing and Combating Violence Against Women and Domestic Violence) in the world with the impact of public oppression on media and its political business cycle. The Convention was ratified by the GNAT in 2012 and entered into force in 2014. At the same time, the Münevver Karabulut murder was on the country agenda due to the way that it was addressed in public opinion and class difference of the suspect, and it was accepted as a symbol case in femicides.

Focusing on the news about the symbol cases, which directly influenced the course of signing the İstanbul Convention, the research particularly addresses the Ayşe Paşalı and Münevver Karabulut murders between 2009 and 2013. The research seeks an answer to the question of what the points of articulation of violence against women to patriarchal sex/sexuality and bourgeoisie/class discourses are. These murdering cases are selected because of the way the media addresses them and the fact that the media categorically segregates them. For this reason, the discourse analysis method is used in the study. Before the findings part in which the news 
is examined, the research questions, sampling selection, developed academic discussion regarding the discourse analysis are summarized and finally conclusion and discussion parts are addressed.

In both femicides examined within the scope of the study, it is seen that the media does not act according to gender equality in their news. In the media language, the masculine/patriarchal perspective is determinative. It is seen that the vicious cycle mutually feeding gender inequality between the media and society is the most effective instrument in normalizing violence against women. On the other hand, placing violence against women on the first page broadly by separating it from the violence problem has led to the emergence of legislative and legal deficiencies in the relevant field, and has also mobilized political decision makers. It is seen that the media with its high social perception power is the most effective instrument that directly impacts the society and decision-making mechanisms. This is why it is necessary to deliver awareness training on gender equality to reporters who go to the scene of crime first to make news, listen to the sources at first hand, build and write news, to editors who decide the presentation style by conducting an editorial check on the reporters' news and to editors in chief. Considering that the society does not direct the media, but the media directs the society, the change in the way of presenting the news in the media will lead to a positive change in the perception of the society.

As a result, while the media indirectly causes violence to continue with justified reasons in the society with the patriarchal discourse it uses in the news of violence against women, it could problematize the issue of violence against women, bring it to the public's agenda and enable policy makers to take action on solution points. In order to root out the problem of violence against women, it could be ensured that the members of the media receive discourse awareness training on gender equality, and they change their discourses through the ombudsman of relevant CSOs. Furthermore, in the media, particularly in the written and visual news, it is needed to take a stand against encouraging gender discrimination and every kind of violence especially violence against women and to conduct awareness raising activities to prevent violence to be presented as usual human nature. Social reactions and sanctions should be applied for the 
expressions insulting women in cultural and artistic products such as written and visual press and films.

\section{Kaynakça / References}

Abu- Lughod, L. (2004). Peçeli duygular. Ertüzen, S. (Çev.). İstanbul: Epsilon Yayınevi.

Akbaba, Z. B. (2008). Töre, namus ve tore saikiyle kasten öldürme. Türkiye Barolar Birliği Dergisi, Sayı 75, 331-351.

Akın, A. (2011, 8 Şubat). Cinayet gününü anlattı. Hürriyet. 20 Temmuz 2021 tarihinde https://www.hurriyet.com.tr/gundem/cinayet-gununu-anlatti$\underline{16967676}$ adresinden erişildi.

Arman, A. (2009, 26 Nisan). Sizin çocuğunuz kafası çöpten çıssa n’apardınız. Hürriyet. 15 Mayıs 2021 tarihinde https://www.hurriyet.com.tr/sizin-cocugunuzun-kafasi-copten-ciksa-n-apardiniz-11514177 adresinden erișildi.

Arman, A. (2009, 28 Nisan). Kızlarına sahip çıksalarmış. Hürriyet. 10 Haziran 2021 tarihinde https://www.ntv.com.tr/turkiye/kose-yazarlarindan-cerrahin-sozlerine-tepki, xFMpitsgPEGlJ1q1-IEdow adresinden erişildi.

Armutçu, O. (2012, 29 Ocak). Evi terk artık indirim nedeni değil. Hürriyet. 20 Temmuz 2021 tarihinde https://www.hurriyet.com.tr/gundem/evi-terkartik-indirim-nedeni-degil-19796135 adresinden erişildi.

Aydın, Ç. (2013, 30 Ocak). Son görüntüde önemli ipucu. Hürriyet. 20 Temmuz 2021 tarihinde https://www.hurriyet.com.tr/gundem/son-goruntude-onemli-ipucu-22479671 edresinden erişildi.

Babacan, N. (2010, 30 Aralık). Eteğimden aşağı çekiyorlar. Hürriyet. 21 Temmuz 2021 tarihinde https://www.hurriyet.com.tr/gundem/etegimdenasagi-cekiyorlar-16645424 adresinden erişildi.

Beauvoir, S. D. (1993). Kadın ikinci cins: Genç kızlık çağı. B. Onaran. (Çev.). İstanbul: Payel Yayınları.

Dijk, T. V. (1999). Söylemin yapıları ve iktidarın yapıları. M. Küçük. (Der.). Ankara: Ark Yayınları, s.331-37.

Dijk, T.V. (2003). Söylem ve ideoloji. B. Çaban. Vd., (Der.). Ankara: Su Yayınları.

Dijk, T.V. (2005). Söylemin yapıları ve iktidarın yapıları. (M. Küçük, Çev.) Medya, iktidar, ideoloji içinde (s.271-312). Ankara: Bilim ve Sanat Yayınlari.

Dijk, T.V. (2010). Söylem ve iktidar. B. Yıldırım. (Der.). Nefret suçları ve nefret söylemi içinde (s.9-14). İstanbul: Hrant Dink Vakfı Yayınları. 
Doğan, C. (2010, 24 Aralık). Koca dayağı, af ve cinayet. HaberTürk. 15 Temmuz 2021 tarihinde https://www.haberturk.com/yasam/haber/584369-kocadayagi-af-ve-cinayet adresinden erişildi.

Doğan, R. (2016). Yargitay kararlarında töre saikiyle öldürme suçu. TTB Dergisi 126, 126-160.

Doltaş, D. (1995). Batıdaki feminist kuramlar ve 1980 sonrası Türk feminizmi. N. Arat. (Der.). Türkiye'de kadın olgusu: Kadın gerçeğine yeni yaklaşımlar içinde (s.51-71). İstanbul: Say.

Güçer, D. (2010, 26 Aralık). Yasalarımıza eksik yok, ayşe paşalı cinayeti münferit. Vatan. 10 Temmuz tarihinde http://www.gazetevatan.com/-yasalarimizda-eksik-yok-ayse-pasali-cinayeti-munferit--349123-gundem/ adresinden erişildi.

Güler, Ü. (2004). Söylem çözümlenmesinde yöntem sorunu ve Van Dijk yöntemi. Ç. Dursun. (Der.). Haber hakikat ve iktidar ilişkisi içinde (s.111148). Ankara: Elips Yayınları.

Ocak, S. (2021, 20 Mayıs). Kadına yönelik şiddetin önlenmesi için 2021 Nisan sonu itibarıyla 17 bin koruyucu tedbir kararı alındı. Anadolu Ajansı. 10 Haziran 2021 tarihinde $h t t p s: / / w w w . a a . c o m . t r / t r /$ adresinden erişildi.

Özbadak, M. (2011, 12 Mayıs). Ayşe Paşalı davasında karar çıktı. Sabah. 10 Haziran 2021 tarihinde https://www.sabah.com.tr/gundem/2011/05/12/ayse-pasali-davasinda-karar-verildi adresinden erişildi.

Öztürk, E. (2010, 11 Şubat). Başını kesip taksi çağırdım. Sabah. 10 Mayıs 2021 tarihinde https://www.sabah.com.tr/gundem/2010/02/11/babanin en cok merak ettigi soru adresinden erişildi.

Kama, A. (2010, 10 Ekim). Münevver Karabulut'un ailesinden Cem Garipoğlu intiharıyla ilgili açıklama. Radikal. 15 Mayıs 2021 tarihinde http://www.radikal.com.tr/turkiye/munevver-karabulutun-ailesinden-cemgaripoglu-intihariyla-ilgili-aciklama-1218169/ adresinden erişildi.

Karapınar, T. (2011, 15 Mayıs). Paşa'lı davası AİHM'de. Milliyet. 10 Temmuz tarihinde https://www.milliyet.com.tr/gundem/pasali-davasi-aihm-de1390460 adresinden erişildi.

Kireklo, G. (2009, 30 Mayıs). Cem bir zamanlar dostumdu şimdi ondan nefret ediyorum. Sabah. 15 Temmuz tarihinde https://www.sabah.com.tr/ adresinden erişildi.

Millet, K. (1987). Cinsel politika kuramı. İstanbul: Payel Yayınları. 
Şener, G., Çavuşoğlu, Ç. ve Irklı, H. İ. (2016). Medya ve toplumsal cinsiyet. F. Saygılıgil. (Der.). Toplumsal Cinsiyet Tartışmaları içinde (s.166-183). Ankara, Dipnot.

Şekeroğlu, M. (2010, 27 Mayıs). Benim ilk ve sonum ol. HaberTürk. 10 Temmuz tarihinde https://www.haberturk.com/yasam/haber/518163-benim-ilkimve-sonum-ol adresinden erişildi.

Tanrı̈over U. H. (2007). Medyada kadınların temsil biçimleri. Alankuş, S. (Der.) Kadın odaklı habercilik içinde (s.154). İstanbul: İletişim Vakfı Yayınları.

Türk Ceza Kanunu, 12.10. 2004, 82 ve 29. maddeleri. 10 Haziran tarihinde https://www.tbmm.gov.tr adresinden erişildi.

Uludağ, A. (2020, 16 Nisan). Türkiye'den Paşalı'yı koruyamadık itirafı. Cumhuriyet. 29 Temmuz 2021 tarihinde https://www.cumhuriyet.com.tr/haber/turkiyeden-pasaliyi-koruyamadik-itirafi-1733301 adresinden erişildi.

Yaktıl, G. (2010). Erkek egemen toplumda gücün kanıtı: Kadına yönelik şiddet ve medyadaki görünümleri. Ö. Özer (Ed.). Medyada şiddet kültürü içinde (s.433-450), İstanbul, Literatürk.

Yegen, C. (2014). İnternet haberciliğinde kadın cinayeti haberlerinin sunumu: posta gazetesi örneği. The Turkish Online Journal of Design, Art and Communication (TOJDAC), 4(3),15-28.

\section{Kaynakça Bilgisi / Citation Information}

Cantürk, S. (2021). Medyanın kadın cinayetlerine bakışı: 2009-2013 dönemi Ayşe Paşalı ve Münevver Karabulut cinayet haberleri örneği. OPUS-Uluslararası Toplum Araştırmaları Dergisi, 18(43), 7028-7054. DOI: $10.26466 /$ opus. 976225. 